\title{
Consumer Choice as the Best Way to Recenter the Mission of Competition Law
}

Robert H. Lande

University of Baltimore School of Law, rlande@ubalt.edu

Follow this and additional works at: http://scholarworks.law.ubalt.edu/all_fac

Part of the Antitrust and Trade Regulation Commons, and the Consumer Protection Law Commons

\section{Recommended Citation}

Consumer Choice as the Best Way to Recenter the Mission of Competition Law, in More Common Ground for International Competition Law? 21 (Josef Drexl, eds., et al., 2011)

This Book Chapter is brought to you for free and open access by the Faculty Scholarship at ScholarWorks@University of Baltimore School of Law. It has been accepted for inclusion in All Faculty Scholarship by an authorized administrator of ScholarWorks@University of Baltimore School of Law. For more information, please contact snolan@ubalt.edu. 


\title{
Consumer choice as the best way to recenter the mission of competition law
}

\author{
$\underline{\text { Robert H. Lande* }}$
}

The mission of competition law needs to be clarified, and this article asserts that the best way to do this is to interpret and enforce these laws in terms of consumer choice. This reformulation is necessary due to uncertainty and instability that exists in the field. For example, even though the United States’ competition laws, which it calls antitrust laws, are more than a century old, it can't decide upon these laws' overall purpose. The 'main point of antitrust' in the United States from 1890 to the 1970 s was a variety of social/political/economic objectives, including the belief that big businesses were suspect and small businesses were good. ${ }^{1}$ Then the efficiency-only paradigm emerged during the Reagan and Bush administrations. ${ }^{2}$ More recently, the Clinton Administration seemed to care about

* Venable Professor of Law, University of Baltimore School of Law, and a Director of the American Antitrust Institute. This chapter is in large part a condensation and update of NW Averitt and RH Lande, 'Using The “Consumer Choice” Approach to Antitrust Law’ (2007) 74 Antitrust Law Journal 175, available at http://papers.ssrn.com/sol3/papers.cfm?abstract_id=1121459 (accessed 25 September 2009). I am grateful to Christine Carey for excellent research assistance.

$1 \quad$ RH Lande, 'Wealth Transfers as the Original and Primary Concern of Antitrust: The Efficiency Interpretation Challenged' (1982) 35 Hastings Law Journal 101-105. See also JB Kirkwood and RH Lande, 'The Fundamental Goal of Antitrust: Protecting Consumers, Not Increasing Efficiency’ (2008) 84 Notre Dame Law

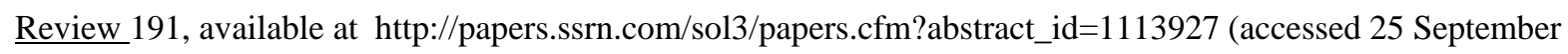
2009).

$2 \quad$ See id. at 191-196. The efficiency approach originated in the 1960s, with Robert Bork, and was spread by Judge Posner and others. This approach did not merely assert that efficiency is important, but rather asserted that efficiency is the only acceptable goal of antitrust. With Reagan's 1980 election, federal enforcement officials who adhered to the efficiency approach were appointed, and it came to dominate antitrust. Today many scholars still exclusively believe in the efficiency goal. This is especially true of economists. 
enhancing economic efficiency and also with protecting consumers from paying more as a result of illegally acquired market power: the 'wealth transfer' or 'protecting consumers' property from theft by market power' reason for competition law. ${ }^{3}$

What does the Obama Administration believe? It is too early to tell, but it is possible that its overriding concern will be different from prior administrations. Of course it will care about efficiency and about consumers paying higher prices, but it might well use as its loadstar an approach focusing on consumer choice. The consumer choice approach began being utilized during the Clinton and Bush administrations, and it often has been used by the European Union. ${ }^{4}$ But it might well be used even more during the Obama Administration.

3 The Clinton Administration did not adhere to any one specific approach and, during its eight years, did not speak with one voice on the subject. Efficiency was a large part of its concern, and there was no inclination to return in any way to a 'big is bad/small is good' philosophy. But it also was concerned with prices to consumers, or 'wealth transfers' from consumers to firms with market power. (When cartels raise prices they cause not only allocative inefficiency, they also cause a transfer of wealth from consumers to firms with market power. RH Lande, 'Wealth Transfers as the Original and Primary Concern of Antitrust: The Efficiency Interpretation Challenged' (1982) 35 Hastings Law Journal 101-105.) This is the theft explanation for antitrust or competition law, and it asserts that these laws are at their core about corporations stealing consumers' property - consumers' surplus. Cartels are undesirable because they unfairly raise prices to consumers above the competitive level and thereby represent a taking of consumers' property by the cartel. Id. at 96.)

Perhaps surprisingly, this same theft or wealth transfer approach also has been adopted by the U.S. Supreme Court. See JB Kirkwood and RH Lande, 'The Fundamental Goal of Antitrust: Protecting Consumers not Increasing Efficiency’ (2008) 84 Notre Dame Law Review 191, at 192, 216-219, http://papers.ssrn.com/sol3/papers.cfm?abstract_id=1113927 (accessed 25 September 2009). Because its last 15 antitrust cases were all decided in favor of the defendants, one might think that the U.S. Supreme Court had endorsed the efficiency paradigm. But these cases may be explained better by a concern with protecting consumers from paying supracompetitive prices than they are with efficiency. Efficiency is important to the Court, but the transfer seems to be even more important. Id.

$4 \quad$ See infra fn 38 and 39. 
This article will (1) define the consumer choice approach to competition law or antitrust law and show how it differs from other approaches; (2) discuss the types of situations where a consumer choice focus is likely to make a difference in enforcement outcomes, producing better results than the other paradigms; (3) show that another important advantage of using the consumer choice approach would be to nudge decisions in the right direction; and (4) offer a brief overview of implementation issues.

\section{What is the 'consumer choice' approach to competition law?}

If you examine every type of competition law or antitrust law violation, from price fixing to predation, and ask what they have in common, the answer is they all significantly restrict consumer choice. Every violation significantly and artificially distorts or diminishes the choices that otherwise would be offered by the free market. ${ }^{5}$ This does not mean everything that significantly reduces consumer choice is, or should be, a violation of competition laws. But if you examine what these violations have in common, it is that they significantly reduce consumer choice.

How does a consumer choice approach differ from either a price approach or an efficiency approach? It is broader than both, and includes both. First, it includes price considerations because consumers should be able to choose from among the price options a free market would provide. Additionally, it encompasses the wealth transferred from

5 For example collusion, including price fixing, and the division of markets and customers, diminish the choices - usually the price choices - available to consumers, and replace price choices determined by competition with price choices determined by collusion. By contrast, procompetitive joint ventures leading to new or less expensive products do not restrict consumer choice. A second example is anticompetitive mergers, which can produce too few firms in the marketplace and thus lead to fewer choices than the free market would offer. Also, monopolization through predation also artificially reduces the choices available to consumers. For an analysis of every antitrust violation in choice terms see RH Lande, 'Consumer Choice as the Ultimate Goal of Antitrust', (2001) 62 University of Pittsburgh Law Review 503, at 506-508. 
consumers to firms acquiring market power (the belief that when cartels raise prices above the competitive level this constitutes the theft of consumers' property). The consumer choice approach also includes efficiency considerations, especially the innovation concern, because optimal innovation gives rise to optimal consumer choice. Because cost savings efficiencies can affect price, these considerations are included as well. But most important, the consumer choice approach also gives a high priority to other consumer concerns such as competition in terms of quality, variety, service, and privacy. ${ }^{6}$

Some other crucial elements of a choice paradigm include the idea that: (1) not every decrease in consumer choice counts as an injury to competition; only significant decreases, but not, for example, a reduction in choice from ten down to nine options; (2) more choice is not necessarily good. The goal of competition policy should not be to maximize choice, but rather to eliminate practices that artificially restrict the choices the free market otherwise would have provided; (3) Although every competition law violation reduces consumer choice, not every reduction in consumer choice violates competition law. Some reductions in consumer choice - such as when a monopolist reduces its variety of offerings - do not violate any law; (4) reductions in consumers' ability to choose from among the offerings the market provides are Consumer Protection violations; ${ }^{7}$ and (5) competition law under a consumer choice perspective would continue to have efficiency defenses since efficiencies can positively affect consumer choice.

$6 \quad$ See NW Averitt and RH Lande, 'Using The “Consumer Choice” Approach to Antitrust Law’ (2007) 74 Antitrust Law Journal, 175, 183, available at http://papers.ssrn.com/sol3/papers.cfm?abstract_id=1121459. (accessed 25 September 2009).

7 Id. at 181-182. 
The overall approach can be illustrated by the most highly publicized U.S. antitrust litigation of our generation - the Microsoft case. ${ }^{8}$ This case illustrates the importance of choice, and illustrates how we have been moving towards a choice paradigm, because it was litigated primarily in 'choice' terms. The products in question were PC operating systems and web browsers. The pertinent briefs and Court decisions reveal that both the litigants and the Court focused primarily on innovation, new products, and short term and long term consumer choice. ${ }^{9}$ Naturally, both sides strongly disagreed about how to maximize consumer choice, but the important point is that price and cost savings were less important concerns. In Microsoft, little attention was paid to the price of the operating system - over which Microsoft had a legal monopoly - or the price of the web browser, which was given away free. Nor were cost savings efficiencies the primary concern. Rather, diminished short term consumer choices, innovation, and the resulting long term choices innovation would have brought, were the key issues. ${ }^{10}$

Even though this article urges that competition law should shift to employing an explicit focus upon consumer choice, Microsoft illustrates that the United States is engaged in a lengthy process of shifting from an efficiency or price approach towards a choice approach, even if choice terminology is not always explicitly used. This case also illustrates how a price or efficiency model often is inadequate to address our concerns in the competition or antitrust area.

\section{When would the consumer choice formulation make a difference?}

$8 \quad$ RH Lande, 'Consumer Choice as the Ultimate Goal of Antitrust'(2001) 62 University of Pittsburgh Law Review, 503, 511-514.

$9 \quad$ Id. at $511-512$.

$10 \quad$ Id. at 511. 
At this point one might think: of course competition law should be concerned about more than just price and cost savings. Of course quality, service, etc. should impact the analysis. However, if a market is competitive in terms of pricing issues, won't it also be competitive in terms of non-price issues? If a market has three firms, or five firms, or whatever number of firms one believes is enough to ensure price competition in a particular market, won't this same number of firms also ensure non-price competition? If so, what is the harm in using just a price standard? Won't ensuring price competition automatically give us the non-price options we want as well?

Normally this is indeed true. Normally there is no difference between a choice approach and a price approach, and therefore little benefit to using a choice standard. For example, suppose there were four firms that made cookies, that three firms are enough to have price competition, and that three firms could make them at the same cost as four. If consumers want twenty different types of cookies, or 200, three firms should be able to supply them just as well as four. If two of the four firms wanted to merge, there would be no advantage to using a choice standard over a price standard or an efficiency standard to assess this merger.

But sometimes it would make a difference. There are three broad categories of cases where a choice analysis could lead to a different (and in each case superior) result: cases in markets with little or no price competition; cases involving conduct that increase consumers' search costs or otherwise impairs their decisionmaking ability; and cases in markets in which firms compete primarily through independent product development and creativity, rather than through price.

\subsection{Markets lacking serious price competition}

The first group of cases involves conduct in markets with little or no price competition as a result of regulation, industrywide joint ventures, or third party payers. In these situations there 
is no way properly to assess consumer welfare without focusing explicitly on non-price issues.

First, consider markets where prices are regulated. For example, airlines in the United States, before they were deregulated, competed in terms of quality and service, as demonstrated by their intense competition over the quality of the meals they served. ${ }^{11}$ A price analysis of this market would have been seriously incomplete. One even could ask why the United States did not permit every airline to merge during the period when their rates were regulated. After all, they could not have raised prices. The answer is that we wanted non-price competition.

Now consider a market where all the significant firms were allowed to merge. Montgomery County, Maryland, allowed both of its major taxicab companies to merge, on the theory that prices were regulated so there could be no harm from this merger. ${ }^{12}$ Unfortunately, as a result of these mergers service and quality went down significantly. ${ }^{13}$ This example illustrates that even if prices are regulated, competition often leads to better service, and the potential harm to consumers in these markets from a lack of competition often are extremely difficult to quantify in price terms.

Second, consider situations involving industrywide joint ventures. ${ }^{14}$ There have been many United States cases, including $\underline{\text { Aspen }}^{15}$ and Broadcast Music Incorporated, ${ }^{16}$ involving all or most all of a relevant market. These joint ventures severely restricted price competition

11 NW Averitt and RH Lande, ‘Using The “Consumer Choice” Approach to Antitrust Law’ (2007) 74 Antitrust Law Journal, 175, 196-197, fns 67-69, http://papers.ssrn.com/sol3/papers.cfm?abstract_id=1121459 (accessed 25 September 2009).

$12 \quad$ Id. at $233-235$.

$13 \quad$ Id. at 234.

$14 \quad$ Id. at $197-198$. Id. at 197 (citing Aspen Skiing Co. v. Aspen Highlands Skiing Corp., 472 U.S. 585 (1985). Id. at 198 (citing Broadcast Music, Inc. v. CBS, 441 U.S. 1 (1979)). 
as a necessary part of their operations, and also involved activity that limited consumer choice. In these cases it would have been meaningless to decide whether the joint venture was procompetitive or anticompetitive by only focusing on price terms because there was only limited price competition in the relevant markets. In each case there was, however, significant non-price competition between the firms that entered into the joint venture. Consumers could pick from among the firms in the market on the basis of service, quality, or another dimension of competition. Alternatively, one could ask why all the firms in these joint venture cases were not allowed to merge since they were setting joint prices already? The answer is that we wanted to preserve choice competition.

Third, consider cases involving third party payers. ${ }^{17}$ Whenever their bills are paid by someone else, consumers are likely to care more about quality, service, and variety than price. If a person knows their medical or car repair bills will be paid by their insurance company, for example, a price model would be woefully inadequate at explaining their behavior.

\subsection{Conduct that increase consumers' search costs or otherwise impairs their decisionmaking ability.}

A second broad category of cases when a consumer choice approach will work better involves conduct that increase consumers' search costs or otherwise impairs their decisionmaking ability. This conduct tends to cause consumers to obtain products or services less suited to their needs, at a cost higher in terms of the value of consumers' time, in addition to adversely impacting price.

In the United States there have been a large number of these cases, including the advertising restriction cases: Bates v. State Bar of Arizona,${ }^{18}$ Mass Board of Optometry, ${ }^{19}$ and

\footnotetext{
$17 \quad$ Id. at $198-199$.

18 Id. at 200 (citing Bates v. State Bar of Arizona, 433 U.S. 350, 384 (1977) (rule forbidding most attorney
} advertising overturned on First Amendment grounds)). 
similar cases that involve collusion to raise consumer search costs, including National Society of Professional Engineers, ${ }^{20}$ and Detroit Auto Dealers. ${ }^{21}$ Prices of the products and services in question - legal services, optician services, cars, etc. - probably increased as this was the

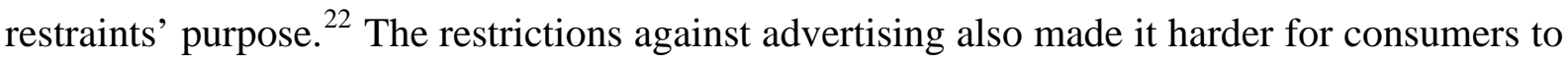
choose the service or product that best suited their needs. ${ }^{23}$ Moreover, consumers' selection of a less optimal engineer, lawyer, optician, automobile, etc. harms their welfare.

In each instance, efficiencies were claimed for the practices. Depending upon the case, the efficiencies were more, or less, believable. ${ }^{24}$

If practices such as these were evaluated under the rule of reason, the negative effects of the practices - both the higher prices and the deleterious effects of consumers obtaining an engineer, lawyer, optician, or automobile that was suboptimal for their purposes - should be balanced against the practices’ efficiencies. If only the negative price effects were included in this tradeoff, the balance easily could come out in favor of the restraint. However, a tradeoff that included the negative effects on consumer choice, as well as the negative price effects, would more accurately measure the effects of the restrictions on overall consumer welfare.

\subsection{Markets in which firms compete primarily through independent product development and creativity, rather than through price.}

19 Id. (citing Massachusetts Bd. of Registration in Optometry, 110 F.T.C. 549 (1988) (board regulations impeding advertising by corporate providers, and prohibiting advertising of discounts, were unauthorized by statute, and condemned as antitrust violations)).

$20 \quad$ Id. (citing National Society of Professional Engineers, 435 U.S. 679, 681 (1978)).

21 Id. at 200-201 (citing National Society of Professional Engineers, Detroit Auto Dealers Ass'n, 111

F.T.C. 417, 681 (1989)).

22 Id.

$23 \quad$ Id. at 200.

24 Id. 
Finally, there are some markets in which firms compete primarily through independent product development and creativity, rather than through price. These markets may involve high-tech innovation or editorial independence in the news media. Effective competition in these industries may sometimes require more independent centers of decisionmaking than are required to ensure price competition, so market concentration principles taken from a price context may not ensure robust competition in the respects that are actually most relevant to consumers. In these cases, competition law decisionmakers should focus upon artificially diminished consumer choice even if prices are competitive. For this reason, in these markets a price standard is inadequate.

For example, the media is an area where society cares a great deal about independent judgment, decisionmaking and creativity. Suppose there were only four remaining media firms of a particular type (such as book publishers, TV, radio or magazine owners) and that two of them wanted to merge. Suppose they could guarantee that the prices of the remaining three firms would remain competitive following the merger. Should society approve this merger? Or would society fear the artificially diminished choice that can result from fewer independent sources of opinion and information? If so, some large media mergers might well be evaluated differently under a choice standard than a price standard.

It might be instructive to contrast a media merger with the earlier example of a conventional merger of cookie making firms. Recall the example where there were only four firms that made cookies, and three would be enough to yield effective price competition. If consumers want twenty or 200 different types of cookies the remaining three firms should supply them. For a hypothetical four to three cookie merger there would be no advantage to using a choice standard over a price standard or an efficiency standard. The key difference is that the owners of the cookie companies don't care which cookies their customers eat, so they will produce whatever kinds of cookies consumers want. 
In contrast, owners of the media might have distinct preferences concerning the editorial content of the news. Within limits they may be able to add their own slant to coverage. Moreover, the media owners might have unconscious biases and presuppositions, so even if they have the best intention they might not be able to supply the full range of views. While companies easily can make many different types of cookies, it is much more difficult to hold all sorts of different worldviews.

To emphasize the point; the United States has six major TV networks. ${ }^{25}$ Should all six be allowed to merge the entirety of their news operations into one? Media pooling is currently permitted, and dozens of newspapers were permitted to form the Associated Press. ${ }^{26}$ Why not allow all six of the major TV networks to merge all of their news operations? This merger would produce very significant cost saving efficiencies. But it is extremely uncertain that it would produce any anticompetitive effects on prices. Because TV news programs compete for advertising dollars and personnel with many other types of televised broadcasts and also to some extent with other forms of media, an anticompetitive price effect would be extremely difficult to demonstrate. The real harm from this news gathering merger, however, could easily be expressed in terms of choice - in terms of perspectives, quality, and varieties of approaches to news coverage. A choice model would account for this harm much better than a price or efficiency model. ${ }^{27}$

\footnotetext{
$25 \quad$ Id. at 235.

$26 \quad$ Id. at fn 226.

27 The Voter News Service (VNS) is also illustrative. See RH Lande, 'Consumer Choice as the Ultimate
} Goal of Antitrust' (2001) 62 University of Pittsburgh Law Review 503, 519-522. At 8:00 pm on 7 November 2000, Election Day in the United States, all the major TV networks declared that Presidential candidate Al Gore won the state of Florida, and therefore the election. Later, at 10:00 pm all the networks simultaneously declared Florida too close to call. Next, the networks called it for Presidential candidate George W. Bush. Then once again, the networks later declared Florida was too close to call. 
Alternatively, consider high technology markets where innovation is crucial. It is virtually meaningless to apply a price standard to evaluate the effects of a merger or joint venture on future technology since that technology does not yet exist. For mergers in the defense, pharmaceutical, computer, or other high-tech sectors, to ensure the optimal level of future consumer choice we want divergent sources of attempts to innovate. Consumers quite often prefer innovation over low prices on existing products. ${ }^{28}$

These situations should be evaluated explicitly and directly as to whether research that might lead to new and better products will be enhanced or eliminated. Price effects also should be evaluated, but a consumer choice approach would, quite properly, intensify the focus on products that might never be invented but for the merger or joint venture. The practices at issue mostly affect non-price competition, so competition law should focus on these issues explicitly. Doing so might sometimes result in the recognition that more firms are needed for innovation or perspective competition than for price competition.

Each network called the state of Florida wrong twice - once for each candidate. Why the uniformity of incorrect results? Previously six election prediction organizations existed independently, but they gradually combined the entirety of their election polling and prediction operations to form the VNS. This produced significant cost saving efficiencies. Did it also have negative effects on prices? It is extremely difficult to find any significant price effects. Whether VNS charged the six news organizations a monopoly price is irrelevant since the six news organizations owned it.

Unfortunately, due to their combination there was no effective competition in terms of choice of information, quality, perspective, or variety of approaches to election prediction. If the VNS were analyzed under the rule of reason, and all that was balanced was its considerable cost savings against its non-existent or highly uncertain price effects, VNS probably would survive an antitrust challenge. But if the balance weighed these cost savings against both the dubious price effects and also the far more certain decrease in quality, fewer independent approaches to election prediction, and less viewer choice, then the case might well come out differently. If there had been competition among six (or even between two) election polling or prediction organizations, the predictions might have been more accurate, and viewer choice would have been greater. Id. 28 Id. at $193-195$. 


\section{$3 \quad$ Implementation Issues}

Competition law cannot seriously consider adopting an overall approach unless it can be implemented in a relatively objective, predictable manner. How does the choice focus compare to the other approaches in terms of predictability? What are the guiding principles for determining how much weight to give to significant decreases in consumer choice? How can we conduct the analysis relatively objectively?

Mergers seem to be the easiest place to discuss implementation issues. The United States Merger Guidelines express concern with the price effects of mergers twelve times, and in a footnote, acknowledge that mergers also can reduce quality, variety, and innovation. ${ }^{29}$ Even the Efficiency section of the Guidelines largely focuses on cost savings rather than innovation. ${ }^{30}$ But, suppose the Guidelines made innovation and the resulting consumer choices a higher priority. As a practical matter, how could it do this optimally?

The best solution might be for the Merger Guidelines explicitly to say there were certain types of markets (including technology, media, fashion, entertainment, etc.) where the need for innovation or perspective competition means that a larger number of firms may be required to have effective choice competition. Mergers in these markets might be evaluated in terms of different concentration levels or different changes in concentration levels. Alternatively, if the enforcers were reluctant to explicitly say that different structural standards should apply to certain markets, as a practical matter consumer choice concerns could be accommodated into merger analysis in these markets in three different ways.

First, choice considerations could simply be used as a tie-breaker or plus factor. If a decisionmaker were deciding the legality of a media merger, for example, and if they were on

\footnotetext{
$29 \quad$ Id. at $188, \mathrm{fn} 41$.

$30 \quad$ Id. at $187-188$.
} 
the margin as to whether to challenge a transaction if they only considered price effects, choice considerations could cause them to make a different decision.

Second, and very similarly, choice considerations could be used as an implicit factor that would operate within the current structure of the Merger Guidelines. Suppose that for industries where price competition was most important, the enforcers would challenge $20 \%$ of above-Guideline mergers. But perhaps for those industries where consumer choice issues were especially crucial - for mergers involving sectors such as high tech industries, media, entertainment, or fashion - the enforcers would block $40 \%$ of above-Guideline mergers. To implement choice concerns this way, as an informal part of the enforcers' discretion, the concentration levels and changes in the Guidelines would not be changed. But the Guidelines would be enforced more vigorously whenever choice competition was especially important.

Third, the Merger Guidelines could make choice analysis a separate explicit factor in the merger review process. Under this approach, a merger should be challenged either if it were likely to lead to higher prices, or if it were likely to lead to significantly less consumer choice because the merger was likely to hinder innovation (the most important factor that determines consumer choice in the long run).

As a practical matter this would mean that the merger investigation and decision would make a separate, high priority, inquiry into both the price and the innovation effects of the merger. This is similar to the way that innovation is already a separate factor in the Federal Collaboration Among Competitors Guidelines. ${ }^{31}$ This inquiry sometimes could lead to a different result from the current price oriented inquiry, especially because not every company within an industry competes substantially through innovation. Some firms instead largely compete by making existing products less expensively, by superior marketing, by superior service, etc. This method of inquiry would be different from attempting to predict whether a particular merger would be likely to lead to more, or to less, innovation (another

$31 \quad$ Id. at 242 , fn 250. 
possible inquiry for the enforcers). Rather, it would mean attempting to ascertain whether particular firms historically had been centers of independent innovation.

Here is how this inquiry could work. Suppose an industry consisted of five firms; A, B, C, D, and E. Suppose the enforcers believe that three firms are enough to have effective price competition in this market, and also that three firms is enough for effective innovation competition. But suppose that only firms A, B and C compete significantly by innovating, that only these three have large research and development budgets, that only these three have a history of making significant innovations. Suppose that firms D and E compete in other ways - perhaps they are imitators that make existing products less expensively. Suppose that firms A and B (two of the firms that compete by innovating) want to merge. Under price analysis we should permit this merger because after the merger there would still be four firms left, and it is stipulated that three firms is enough for effective price competition.

But under choice analysis we should block the merger because it is likely to lead to less innovation, the long term source of optimal consumer choice. Regardless which number of firms we believe is necessary for effective competition, choice analysis could lead to tougher merger enforcement. ${ }^{32}$

\section{Conclusions}

Nudge, a book by Cass Sunstein and Richard Thaler, stresses the importance of starting points, presumptions and the questions that are first asked. ${ }^{33}$ This book persuasively demonstrates how actions that non-coercively tend to point decisionmakers in particular

\footnotetext{
32 This is analogous to a unilateral effects analysis, which proposes that we should be especially tough on mergers between two firms producing goods within the same niche of a relevant market, and more lenient on mergers between firms producing dissimilar goods. Choice analysis arguably also could be said to create a 'submarket' consisting of innovators, or an 'innovation market', within a broader market. Id. at 215-216. 
directions often affect the outcome of a wide variety of situations. This principle also illustrates the importance of the choice focus: if used as a starting point it often will nudge antitrust law or competition law towards incorporating choice considerations more fully and carefully.

This would be desirable because consumers don’t just want low prices. They want options. This is an important reason why consumer choice is an emerging way to explain and analyze potential competition law violations. Consumer choice analysis in most cases would produce the same result as price or efficiency analysis. But factors like innovation, perspectives, quality, service, privacy, and safety now all too often remains in the footnotes of the analysis, where they are all too-often forgotten. The consumer choice approach would in effect move them into the text, where they would play a more prominent role in the evaluation. As noted throughout this article, the consumer choice mission could lead to better case analysis in several important and general types of situations. ${ }^{34}$

The consumer choice approach also has the advantage of explaining accurately and simply, in a way that everyone can understand, why competition is good for consumer welfare. It is the best, the most intuitive way, to explain the advantages of free competition to a diverse array of audiences, including judges, legislators, the media, and the public.

As a final example, to show how much clearer and easier to understand the choice formulation is, and how awkward and non-intuitive the other approaches to competition policy can be, consider an old case brought by the U.S. Federal Trade Commission ('FTC')

\footnotetext{
34 In addition, the Choice approach will not lead to a worse analysis than a price or efficiency approach. See generally NW Averitt and RH Lande, ‘Using The “Consumer Choice” Approach to Antitrust Law’ (2007) 74 Antitrust Law Journal 175, http://papers.ssrn.com/sol3/papers.cfm?abstract_id=1121459 (accessed 25 September 2009). Moreover, the choice approach is as easy to implement, and as predictable, as a price or

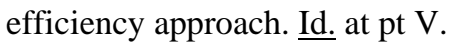


against firms’ jointly set advertising restrictions concerning the safety of bulletproof vests. ${ }^{35}$ A trade association of manufacturers of bulletproof vests adopted a rule that it was unethical for members to advertise safety or to claim their products were safer. The FTC's concern was that without safety advertising consumers might purchase bullet-proof vests that were less safe than they would prefer. ${ }^{36}$

Would anyone be satisfied if their bullet proof vest performed poorly so long as it was sold at a competitive price? In theory, we could translate safety harms caused by advertising restrictions into price harms or efficiency harms using complex Procrustean intellectual gymnastics. But, wouldn’t it be better for the enforcers to straightforwardly say that consumers care about safety, so the enforcers were going to focus on that form of competition explicitly?

The Bush Administration was dominated by the belief that competition laws only should be analyzed in terms of economic efficiency. ${ }^{37}$ For this reason, during the last eight years there was very little chance of arriving at an international consensus as to the main goal of competition policy. By contrast, the European Union seems to have given choice issues a higher priority, as demonstrated by its recent Article 82 policy statement ${ }^{38}$ and the relevant case law. ${ }^{39}$

35 See discussion at NW Averitt and RH Lande, 'Consumer Sovereignty: A Unified Theory of Antitrust and Consumer Protection Law’ (1997) 65 Antitrust Law Journal 713, 750, http://papers.ssrn.com/sol3/papers.cfm?abstract_id=1134798 (accessed 25 September 2009). $36 \quad \underline{I d}$. Commission's Enforcement Priorities in Applying Article 82 EC Treaty to Abusive Exclusionary Conduct by Dominant Undertakings at the European Commission Review of Article 82, that came out in 2008, stated: '[i]n applying Article 82 to exclusionary conduct by dominant undertakings, the Commission will focus on those types of conduct that are most harmful to consumers. Consumers benefit from competition through lower prices, 
Today there is optimism that United States antitrust enforcers might well vigorously adopt the consumer choice formulation and mission. If they do, there might be a chance that

better quality and a wider choice of new or improved goods and services.' Commission of the European Communities, Guidance on the Commission's Enforcement Priorities in Applying Article 82 EC Treaty to Abusive Exclusionary Conduct by Dominant Undertakings at the European Commission Review of Article 82 (3 December 2008) para 5. The report recognized that 'competitors who deliver less to consumers in terms of price, choice, quality and innovation will leave the market.' Id. at para 6. 'In this document, the expression "increase prices" includes the power to maintain prices above the competitive level and is used as shorthand for the various ways in which the parameters of competition - such as prices, output innovation, the variety or quality of goods or services - can be influenced for the profit of the dominant undertaking and to the detriment of consumers.' Id. at para 11. Additionally, the reported clarified that '[t]he aim of the Commission's enforcement activity in relation to exclusionary conduct is to ensure that dominant undertakings do not impair effective competition by foreclosing their rivals in an anticompetitive way and thus having an adverse impact on consumer welfare, whether in the form of higher price levels than would have otherwise prevailed or in some other form such as limiting quality or reducing consumer choice.’ Id. at para 19.

39 See Independent Music Publishers \& Labels Association (Impala) v Commission of the European Communities [2006] ECR II 02289, para 107 ('The Commission also failed to consider whether the concentration might result in an ability to reduce supply, in terms of numbers of new titles or in terms of originality of new releases, or whether it would impoverish creativity, quality and diversity in musical choice... or would have an impact on consumer choice, as it had done in the statement of objections in the EMI/Time Warner case (see point 55, which deals with marginalization of the independents and its impact on the choice and diversity of music being offered to the public). Last, the analysis took no account of Article 151(4) EC or of cultural diversity.'); Van den Bergh Foods Ltd v Commission of the European Communities [2003] ECR II 04653, para 152 ('The exclusivity clause constitutes a barrier to market entry and to the expansion of the relevant market .... Retailers are prevented from exercising their freedom of choice with regard to the products that they wish to stock and to the optimization of space at the sales outlets. Moreover, consumer choice is reduced.'); Roberts v Commission of the European Communities [2001], ECR II 01881, para 40 ('In this respect, the Commission rightly observes in its pleadings that the consumer's choice between those establishments is influenced primarily by their environment and atmosphere, even within the sub-category of pubs distinguished by the applicants.'). 
the international community could at least think about working together towards a common understanding about the primary goal of competition policy. 